\title{
Ethnocultural Voting Trends in Rural Iowa, 1890-1898
}

Bruce Gunn Kelley

NiNETEENTH CENTURY AMERICAN POLITICAL HISTORY IS BEING re-evaluated in terms of the ethnocultural model of voting. ${ }^{1}$ The ethnocultural model claims that ethnic and religious background was normally more influential than any other factor in determining a person's voting behavior. As historian Paul Kleppner notes:

Partisan affiliations were not rooted in economic class distinctions. They were political expressions of shared values derived from the voter's membership in, and commitment to, ethnic and religious groups. Collectively, such values provided the voter with a perspective through which he filtered existential stimuli and by means of which he translated an array of diverse events into personally relevant terms. ${ }^{2}$

Many ethnocultural historians have applied the model to nineteenth century midwestern politics and concluded that in the final quarter of the nineteenth century midwestern ethnocultural groups voted as blocs. ${ }^{3}$ With varying degrees of unity these groups supported the Republican or Democratic party. Kleppner estimated this support for the years between the Civil War and the 1890 s (see Table I). ${ }^{4}$

${ }^{1}$ See J. E. Wright, "The Ethnocultural Model of Voting," The American Behavioral Scientist, XVI, 5 (1973), 653-74; and R. P. Swierenga, "Ethnocultural Political Analysis a New Approach to American Ethnic Studies,” Journal of American Studies, V, 1 (1971), 59-79, for discussions of the theory behind the model.

${ }^{2}$ Paul Kleppner, The Cross of Culture: A Social Analysis of Midwestern Politics, 1850-1900 (New York, 1970), 35.

${ }^{3}$ In addition to Kleppner's The Cross of Culture, Richard J. Jensen, The Winning of the Midwest: Social and Political Conflict, 1888-1898. (Chicago, 1971) and Frederick Luebke, Immigrants and Politics: The Germans of Nebraska, 1880-1900, (Lincoln, 1969), are studies of Midwestern politics using the ethnocultural model of voting.

${ }^{4}$ Kleppner, Cross of Culture, 70. 
Nineteenth century ethnocultural groups are divisible, according to the model, into two groups: liturgicals and pietists. The liturgicals stressed belief in doctrine (or faith), while the pietists emphasized the close association of salvation with personal behavior. Liturgicals believed the sinful world might be accepted as such, but the pietists believed they were divinely enjoined to change the world. The ethnocultural model maintains that the more liturgical "the religious orientation of the group, the more likely it was to support the [Democratic party]; conversely, the more pietistic the group's outlook the more intensely Republican its partisan affiliation." 5 Among the most important liturgical groups were Irish, German, and Bohemian Catholics, as well as German Lutherans. The pietists included Danish, Norwegian, and Swedish Lutherans, as well as Dutch Reformed.

TABLE I

\begin{tabular}{|c|c|c|c|}
\hline \multicolumn{2}{|c|}{ Ethnocultural Group } & Dem. \% & Rep. \% \\
\hline \multirow{4}{*}{ 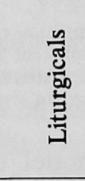 } & Irish Catholic & 95 & 5 \\
\hline & German Catholic & 85 & 15 \\
\hline & Bohemian Catholic & 80 & 20 \\
\hline & German Lutheran & 55 & 45 \\
\hline \multirow{4}{*}{ 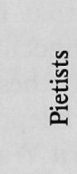 } & DanishLutheran & 45 & 55 \\
\hline & Dutch Reformed & 30 & 70 \\
\hline & Norwegian Lutheran & 30 & 70 \\
\hline & Swedish Lutheran & 10 & 90 \\
\hline
\end{tabular}

Before the 1890s this liturgical/pietistic split largely defined voter choice. In the 1890 s, however, these distinctions blurred as voters shifted in response to the issues of that troubled decade. The nineties were politically turbulent. Three men sat in the White House-Benjamin Harrison, Grover Cleveland, and William McKinley. Only Cleveland was a Democrat. As the decade began, the nation seemed prosperous, but among farmers and

${ }^{5}$ Ibid., 35. 
debtors there was much discontent. In 1890 farmers received only thirty-five per cent of the 1866 price level for their crops. Deflation hit farmers hard because the prices they received for their crops continued declining while the interest they had contracted to pay on their debts stayed constant. This discontent was the force behind the Populist party. In 1892 Populist presidential candidate James B. Weaver, an Iowa native, polled over a million votes. The depression of 1893 then fueled further discontent, resulting in electorial upheaval in the election of 1894 . Because Democrats controlled both houses of Congress and the executive branch, voters blamed Democrats for the depression; and consequently turned to the Republican party for new leadership. In the 354-member United States House of Representatives, Democrats lost 116 seats, a third of the total membership, and Republicans gained control. A weakened Democratic party was captured by the silver (pro-inflation) Democrats at the 1896 presidential convention with the nomination of William J. Bryan. ${ }^{6}$

In the election of 1896 liturgicals and pietists were confronted with issues challenging the foundations of their political ideologies. Republican wooed liturgicals by promising the gold standard and sound money, meaning deflation; while Democrats wooed the normally Republican pietists with their candidate-Bryan-who appeared as an evangelical crusader in a moral crusade. Byran hoped to convert reform-minded Republicans and Prohibitionists, with pietistic religious views, by appealing to their evangelical religions. William McKinley and his Republican strategists took a different approach. They appealed to Catholics and German Lutherans by rejecting prohibition and nativism, but in a quiet way so as to maintain their support among pietists and the xenophobic. Republicans were the moderates of the 1896 election, and their strategy was successful. The 1896 Republican presidential ticket increased its support from nearly all ethnic groups over 1892 and won the presidency. ${ }^{7}$

During the nineties, therefore, a realignment of voters

'See: James L. Sandquist, Dynamics of the Party System: Alignment and Realignment of Political Parties in the Untied States (Washington, 1973), 120-54 for a discussion of the realignment of the parties in the 1890's.

'Sandquist, Dynamics of the Party System, 152. 
occurred. Patterns of voting common since the Civil War were upset. Democratic support declined among most ethnocultural groups, most prominently among those in cities. ${ }^{8}$ Ethnic voters of the rural Midwest, however, also realigned. Though not all groups showed equal declines in Democratic support, the Republican shift was made up disproportionately of voters belonging to Catholic, German Lutheran, and other liturgical religious groups, up to then predominantly Democratic. ${ }^{9}$

Historian Richard Jensen specifically applied the ethnocultural model to Iowa politics in the 1890 s, concentrating upon Iowa's Germans. Jensen treated Germans as a group and did not distinguish between German Catholics and German Lutherans. By charting their voting patterns through the nineties Jensen found Germans gave Democrats less support in 1896 than earlier in the decade. Jensen attributed this change to the Republican de-emphasis of prohibition. The data base for Jensen's conclusions was the Republican percentage of the total vote in fourteen predominantly German counties, as well as nine Iowa city wards. ${ }^{10}$

Jensen also surveyed some other Iowa ethnic groups. Among liturgicals he found Irish in seven rural Iowa townships strongly Democratic, and a similar Democratic trend within seven Bohemian wards and townships. Among pietistic groups Jensen located eleven rural Norwegian townships and found Republicans received eighty-three per cent of the 1896 vote. Further, in six rural Iowa Swedish townships Jensen found McKinley received seventy-four per cent. ${ }^{11}$ In 1896 , Iowa ethnics that Jensen surveyed showed an increased Republican voting percentage over 1892 .

In locating his townships Jensen did not consult the highly useful Iowa manuscript census for 1895 , a census that includes the religious belief and birthplace of each enumerated person, which allows determination of the exact number of voters and their ethnic and religious backgrounds. The present study used this 1895 census and located over one hundred Iowa townships with large concentrations of certain ethnic groups. The analysis

'Ibid., 147.

'Ibid., 152.

${ }^{10} \mathrm{Jensen}$, Winning of the Midwest, 294. 444

"Ibid., 297. (the identity of these townships is unavailable). 
that follows, based on these township data, is an effort to determine whether the ethnocultural model of voting explains the political behavior of rural Iowa ethnics during the 1890s.

BETWEen 1880 AND 1900 The population of Iowa increased fifteen per cent to $1,912,297$, an increase partially attributable to foreign immigrants. In 1900, seventeen per cent of the Iowa population was foreign born, for Iowa the highest percentage before or since..$^{12}$ As Map I shows, many rural townships had large concentrations of ethnics. A few cities also contained a majority of ethnics: Orange City (Dutch Reformed), Pella (Dutch Reformed), Emmetsburg (Irish Catholic), and Decorah (Norwegian Lutheran).

During the nineties Iowa was recovering from a politically traumatic decade. In the eighties the issue of prohibition commanded the center of the political stage. In 1882, Iowa voters ratified an amendment to the Iowa Constitution outlawing the manufacture and sale of liquor, with the Republican party's vocal support. In later elections this stand cost Republicans many votes. Germàn Lutherans, and others who saw nothing wrong with liquor consumption, were estranged in large numbers from the Republican party and drifted to the Democratic party, resulting in Democratic victories in the late eighties and early nineties. By 1890 the Republican party had declined from political dominance to near parity with the Democratic party. The Democratic rise peaked in 1889 and 1891 with the election and reelection of Horace Boies, its gubernatorial candidate. Boies's victories were the result of large increases in the Democratic vote, especially among German districts. ${ }^{13}$

To regain its prominence, the Republican party in the nineties needed to woo these defectors back. Recognizing this, the party de-emphasized prohibition and triggered a Republican resurgence. This de-emphasis was successful because in the elections of 1893 and 1894 Republicans, aided by a favorable national trend as a result of the "Cleveland" depression of 1893 , were able to recapture the governorship and increase their presence in Congress and the Iowa legislature. In 1896 William

${ }^{12}$ Leland L. Sage, $A$ History of Iowa (Ames, 1974), 201.

${ }^{13}$ Jensen, Winning of the Midwest, 97. 


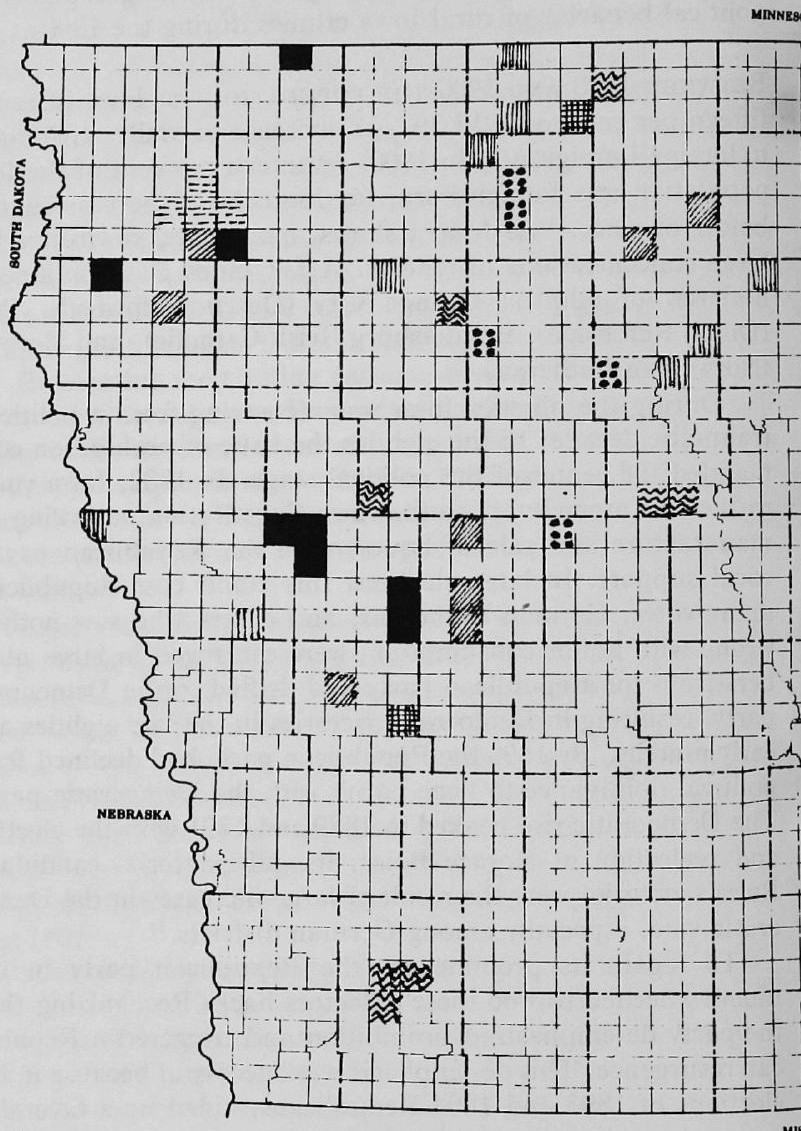

Key

German Catholic

페III) Norwegian Lutheran

German Lutheran
Luxemburg Catholic

[E. Irish Catholic

国 Bohemian
Tㅁ.IIII Danish Lutheran

廆 Swedish Protestant

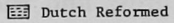

*This map does not purport to indicate all such ethnic concentrations. 


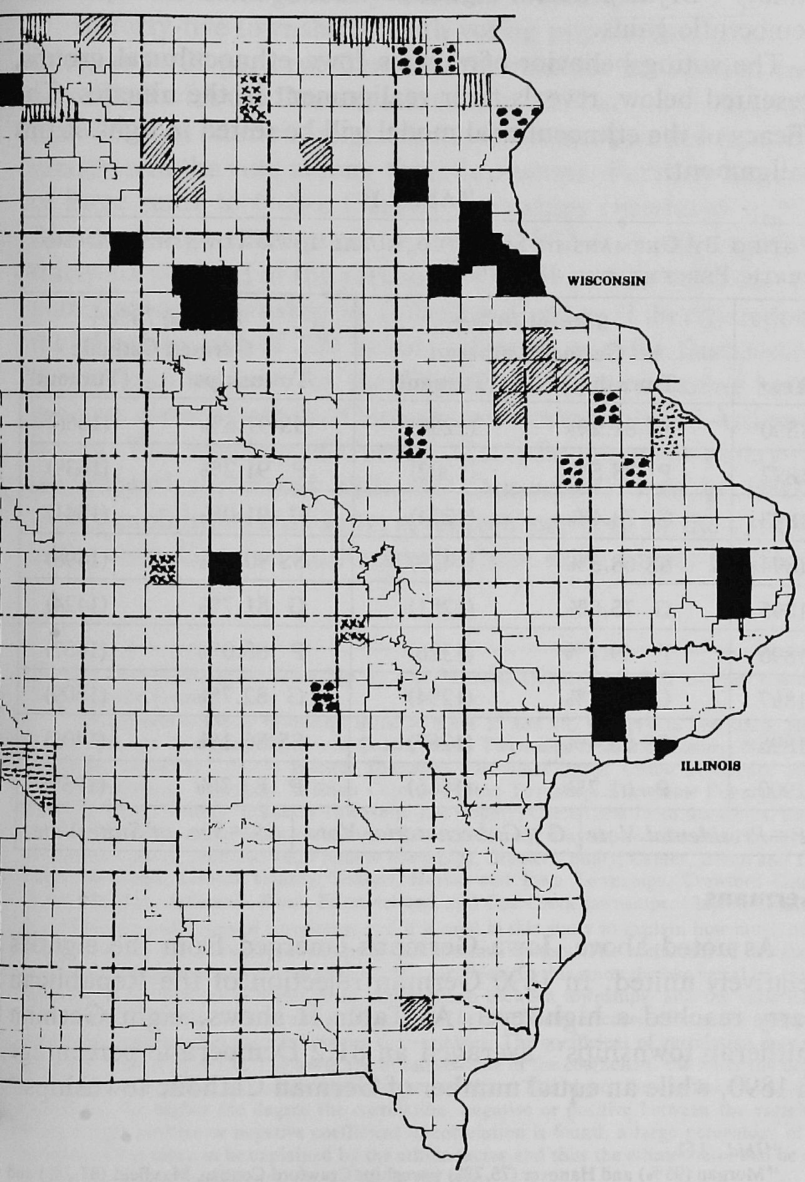


Jennings Bryan, running on the Democratic ticket and emphasizing silver and currency inflation, lost in Iowa to William McKinley. ${ }^{14}$ Bryan's defeat signalled further erosion of previous Democratic gains.

The voting behavior of various Iowa ethnocultural groups, presented below, reveals their realignment in the nineties. The efficacy of the ethnocultural model will be tested in light of this realignment.

TABLE II

\begin{tabular}{|c|c|c|c|c|}
\hline \multicolumn{5}{|c|}{$\begin{array}{l}\text { Voting By Germans in Selected Rural Iowa Townships; Demo- } \\
\text { Cratic Percentages: } 1890-1900\end{array}$} \\
\hline \multirow[b]{2}{*}{ Year } & \multicolumn{2}{|c|}{$\begin{array}{l}8 \text { Rural } 70 \%+ \\
\text { German Lutheran }\end{array}$} & \multicolumn{2}{|c|}{$\begin{array}{l}8 \text { Rural } 70 \%+ \\
\text { German Catholic }\end{array}$} \\
\hline & Townships & (Turnout) & Townships & (Turnout) \\
\hline 1890 & SS $81.2 \%$ & (1268) & SS $91.6 \%$ & $(1666)$ \\
\hline 1892 & P $78.5 \%$ & (1302) & P $\quad 91.2 \%$ & (1639) \\
\hline 1893 & G $78.4 \%$ & (1274) & G $91.0 \%$ & $(1541)$ \\
\hline 1894 & SS $68.3 \%$ & (1429) & SS $90.6 \%$ & (1498) \\
\hline 1895 & G $75.6 \%$ & $(1281)$ & G $81.7 \%$ & (1424) \\
\hline 1896 & P $49.2 \%$ & (1326) & P $\quad 85.0 \%$ & $(1657)$ \\
\hline 1897 & G $66.0 \%$ & (1294) & G $82.7 \%$ & (1509) \\
\hline 1898 & SS $62.4 \%$ & $(1267)$ & SS $86.1 \%$ & $(1401)$ \\
\hline 1900 & P $\quad 61.7 \%$ & (1566) & P $83.7 \%$ & (1755) \\
\hline \multicolumn{2}{|c|}{$P=$ Presidental Vote } & ubernatoric & \multicolumn{2}{|c|}{$S S=$ Sec. of State Vote } \\
\hline
\end{tabular}

\section{Germans}

As noted above, Iowa Germans emerged from the eighties relatively united. In 1890 German rejection of the Republican party reached a high level. As Table II shows, eight German Lutheran townships ${ }^{15}$ averaged an 81.2 Democratic percentage in 1890 , while an equal number of German Catholic townships ${ }^{16}$

${ }^{14}$ Ibid., 112.

${ }^{15}$ Morgan $(96 \%)$ and Hanover $(75.7 \%)$ townships Crawford County, Maxfield $(87.2 \%)$ and Warren $(72.3 \%)$ townships Bremer County, Garnavillo Township $(75.5 \%)$ Clayton County, Grant Township (75\%) Plymouth County, Kane Township (76.6\%) Benton County, and Rockingham Township (72.0\%) Scott County.

${ }^{16} \mathrm{New}$ Wine $(90.9 \%)$, Liberty $(89.4 \%)$ and Dyersville $(76.2 \%)$ townships Dubuque County, Roselle $(91.6 \%)$ and Kneist $(88.2 \%)$ townships Carroll County, Bremen Township $(88.9 \%)$ 448 
averaged a Democratic percentage of almost ninety-two per cent. This near-unanimous Democratic support was also evident in other less homogenously German townships.

In forty-five townships ${ }^{17}$ with voting populations of between thirty and 100 per cent German, the number of German voters correlated with the Democratic vote in 1892 at +.48 , indicating that German ethnicity explains nearly twenty-five per cent of the variation in the vote among these townships. Further, the voters of these same forty-five German townships correlated with the Democratic percentage of the vote in 1892 at +.60 , explaining thirty-six per cent of the variation of the vote.* In 1890 one German Catholic township in Dubuque County (Liberty) reported the ultimate: out of 230 ballots, all were cast for Democrats!

German support for the Democratic party in some heterogeneous areas where the Germans were outnumbered was not as strong. The number of German Catholic voters in ninety-four townships ${ }^{18}$ correlated with the Democratic vote in 1892 at +.41 , explaining only some seventeen per cent of the variation in the vote. German Lutherans in these same ninety-four town-

Delaware County, Stacyville Township (71.8\%) Mitchell County, and East Orange Township $(70.8 \%)$ Sioux County.

${ }^{17}$ In addition to the 16 townships listed in notes 15 and 16; Westphalia Township, Shelby County; Marion Township, Plymouth County; Iowa Township, Dubuque County; North Fork Township, Delaware County; Horton Township, Osceola County; Union Township, Worth County; Caledonia Township, O'Brien County; Fulton Township, Muscatine County; Cleona Township, Scott County; Franklin Township, Lee County; Carroll and Eden townships, Carroll County; Riverdale and Prairie townships, Kossuth County; Dayton and Deerfield townships, Chickasaw County; Jefferson and Fremont townships, Bremer County; Center, Berlin and Deep Creek townships, Clinton County; Soldier, Hayes, and Iowa Townships, Crawford County; Grand Meadow, Jefferson, Read, Farmersburg, and Cox Creek townships, Clayton County.

*This is a coefficient of correlation and it is used in this study to explain how much of the variation in the vote between townships is due to ethnic factors. The coefficient of correlation measures the degree of correlation between two variables. In this study the two variables are the variation in the number of voters of an ethnic group between townships, and the variation in Democratic vote between these same townships. The coefficient of correlation seeks to explain how great a relationship there is between the variables. The coefficient of correlation may vary from -1.0 to 0.0 to +1.0 . The lower the absolute value of the coefficient, the lower the degree of correlation, negative or positive between the variables. The higher the absolute value of the coefficient, the higher the degree the correlation, negative or positive between the variables. When a high positive or negative coefficient of correlation is found, a large percentage of the variation of the vote can be explained by the ethnic factor and thus the ethnic factor can be said to have contributed significantly to a shift in the vote.

${ }^{18}$ The 95 townships used here and elsewhere are: all townships listed in notes $15,16,17,26$, 36,37 , and 38 plus the Dutch townships of Capel, Floyd, Holland, and West Branch, Sioux County and Summit and Lake Prairie, Marion County; the Danish townships of Denmark, Emmet County and Jackson, Shelby County; and the Luxemburger townships of Prairie Springs, Jackson County and Mosalem, Dubuque County. 
ships correlated with the Democratic vote in 1892 at a slightly weaker +.37 . Later in the decade such high levels of Democratic support among Germans were not as common. The depression of 1893 followed the election of 1892 and is generally seen as the reason Germans voted increasingly Republican. ${ }^{19}$ Many of these Germans were rich and well informed. The depression under Cleveland, a Democrat, convinced them of the need for new policies, and Republicans offered the gold standard and a high protective tariff.

That Germans voted more Republican after 1892 has long been known. Following the election of 1894, the editor of the People's Press of Mapleton in Monona County (a heavily Populist county along the Missouri River) printed this tenable bit of political analysis: "The German vote of Iowa largely returned to the standard of protection and sound money." ${ }_{20}$ But questions about this swing have needed answers. How Republican did Germans become? Was there any difference between the Republicanism of German Catholics and German Lutherans?

Richard Jensen attempted an answer in The Winning of the Midwest when he observed that the Germans "lagged in shifting to the GOP in 1893 and 1894 , but led the march to the Republican banner in 1896." Jensen attributed this shift to a revolt by Germans against Bryan's moralism, believing that "the German taste for sound money and distaste for millenarianism cut across all religious, occupational, and political lines." ${ }_{21}$ By this statement Jensen implied that both German Catholics and German Lutherans switched to the Republican party at the same rate. As Table II shows, for rural Iowa, this was not true.

In the election of 1894 German Lutheran support of the Democratic party dropped to sixty-eight per cent from the seventy-eight per cent of 1893. German Catholics, however, gave Democrats ninety-one per cent of their vote, the same percentage as 1893. At issue in the 1894 election was the depression. Clearly, German Lutherans were more revolted by the depression than were German Catholics. The difference in voter

${ }^{19}$ Sandquist, Dynamics of the Party System, 145. tion.

${ }^{20}$ Peoples' Press (Mapleton, Iowa), November 10, 1894, 1. This was a Republican publica${ }^{21}$ Jensen, Winning of the Midwest, 292. 
turnout from election to election in these heavily German townships is significant. For German Lutherans the average turnout for the period was 1,334 voters (or 90.8 per cent of the total eligible voters based on the 1895 census). The election of 1894 saw a much heavier German Lutheran vote, as seven per cent more voters ballotted than usual. Apparently, German Lutherans were very concerned with the issues of 1894 , the foremost being the depression. German Lutherans also voted ten per cent less Democratic in 1894 than they had in 1892 and 1893, thereby apparently expressing their dissatisfaction with Grover Cleveland. Eighteen hundred ninety-six, however, brought a decline in voter turnout from the high turnout of 1894 .

Looking at 1896 voter turnout, 103 votes less than 1894, some German Lutherans apparently could not decide between McKinley and Bryan; so they stayed home. Many of those who did vote, however, switched to McKinley, but their Republican voting was short-lived. With the Democratic per cent of the vote bouncing back up to sixty-six per cent in 1897 , and sixty-two per cent in 1898, the deviant nature of the 1896 German Lutheran vote becomes evident.

German Catholics during the nineties had the opposite pattern of voter turnout, showing a low level of participation in 1894 and a high level of participation in 1896. Some German Catholics apparently were so upset by the hard times in 1894 that they could not vote for their historic party, the Democratic party. But these same German Catholics also could not bring themselves to cast a Republican ballot; so they stayed home. In 1896 German Catholics registered a high turnout for Bryan, seeming to contradict the thesis that German Catholics were revolted by the views of the silver tongued orator from Nebraska. ${ }^{22}$ If they were revolted, they did not show revulsion by their vote.

When the number of German Lutheran voters in ninety-four townships are correlated with the change in Democratic vote between 1892 and 1896, a strong negative correlation results. German Lutherans across Iowa shifted away from the Democratic Party between 1892 and 1896. German Catholics, however, in the same ninety-four townships correlated with the change in

${ }^{22}$ See: Kleppner, Cross of Culture, 333. 
Democratic percentage of the vote between 1892 and 1896 at a very weak +.11 . But more significantly, these same voters correlated at +.48 with the 1896 Democratic percentage of the vote; indicating that German Lutheran ethnicity explains nearly one-fourth of the variation in the vote. Finally, Germans of forty-four heavily German townships correlated with the 1896 Democratic percentage at +.36 and correlated with the change in Democratic percentage between 1892 and 1896 at - 48 .

Two conclusions are discernable: Germans became less Democratic during the nineties, and German Lutherans voted Republican in greater numbers than German Catholics. These conclusions are generally consistent with the behavior of Germans in other midwestern states. In Michigan, Kleppner found the 1896 decline in the Democratic vote was "severe among German Lutheran voters" and strongly committed Democratic Lutherans whose support had hardly wavered even during the depression of 1894, but who "revolted when their party embraced Bryan in 1896." ${ }^{23}$ (Looking at Table II, however, it is clear Iowa German Lutherans did waver in 1894.) Frederick Luebke concluded similarly about the divergent voting of German Lutherans and German Catholics in Nebraska, observing that "church affiliation is the best guide to variation in political behavior among the Germans of Nebraska."”24

Evidently the model is efficient in explaining the realignment of Iowa Germans, especially when German Catholics and German Lutherans separated.

\section{Norwegian Lutherans}

The model would predict Iowa Norwegian Lutherans strongly Republican-and historically Iowa Norwegian Lutherans have been strongly Republican. ${ }^{25}$ This was also true in the nineties. The Democratic percentage of the vote fell slightly in heavily Norwegian Lutheran areas, but Republican candidates were already receiving over eighty per cent of the vote, so these shifts among Norwegian Lutheran voters did not alter their Republican politics.

\section{${ }^{23}$ Ibid.}

${ }^{24}$ Luebke, Immigrants and Politics, 116.

${ }^{25}$ Kleppner, Cross of Culture, 71. 
Ethnocultural Voting Trends in Rural Iowa

MAP II

Monona County: 1896 Vote and Norwegian Lutheran Vote WOODBURY COUNTY

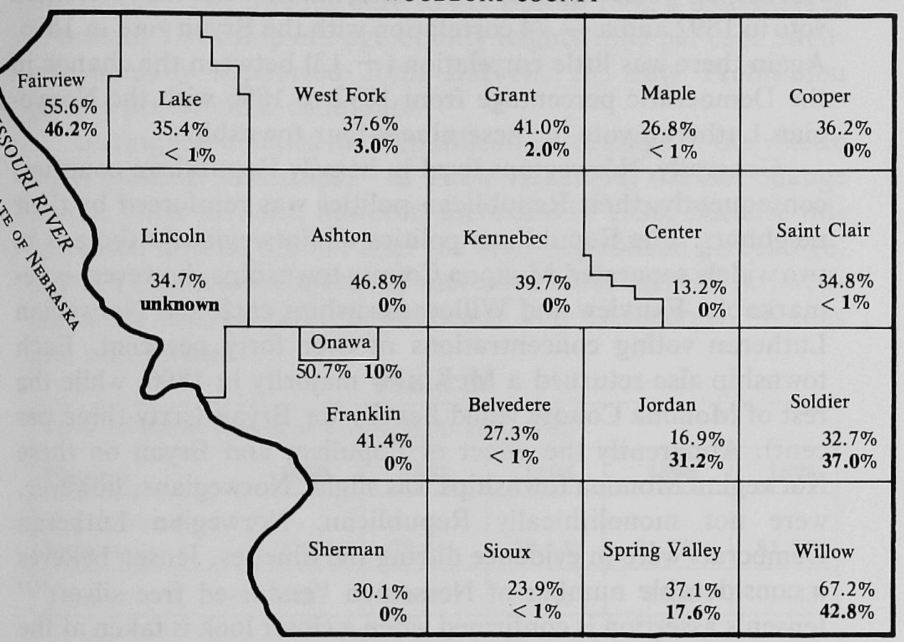

Key:

HARRISON COUNTY

The figure at the top in each township is the Republican percentage of the total vote in 1896. The figure in boldface at the bottom is the Norwegian Lutheran percentage of the voting population.

Twenty-one Norwegian Lutheran townships ${ }^{26}$ correlated with the Cleveland vote of 1892 at an expected - 83 ; consequently, Norwegian ethnicity explains sixty-nine per cent of the variance in the vote. Four years later the correlation in these same twenty-one townships with the Bryan vote was an equally predictable $-\mathbf{7 7}$. Correlating Norwegian ethnicity and the change in the Democratic percentage between 1892 and 1896 results is almost no correlation $(+.16)$.

${ }^{26}$ Silver Lake $(98 \%)$, Brookfield $(95.6 \%)$, and Bristol $(66.7 \%)$ townships Worth County; Norway Township (95.0\%) Winnebago County; Scott Township (94\%) Hamilton County; Highland $(91.5 \%)$ and Hesper $(\mathbf{4 3 \%})$ townships Winneshiek County; Howard Township $(85.1 \%)$ Story County; Norway Township $(81.6 \%)$ Humboldt County; High Lake $(70 \%)$ and Ellsworth $(47 \%)$ townships Emmet County; Otrano $(60.2 \%)$ and Cedar $(52.0 \%)$ townships Mitchell County; Barnes Township $(60.2 \%)$ Buena Vista County; Norway Township $(50.8 \%)$ Wright County; Badger Township (49.7\%) Webster County; Waterloo $(49.4 \%)$ and Center $(43.4 \%)$ townships Allamakee County; Fairview $(\mathbf{4 6 . 2 \% )}$ ) and Willow $(42.8 \%)$ townships Monona County; and Lost Island Township (36.7\%) Palo Alto County. 
This anti-Democratic voting also occurred in heterogenous Norwegian areas. In ninety-four Iowa townships the number of Norwegian voters had a -.79 correlation with the Cleveland vote in 1892 and $\mathrm{a}-.74$ correlation with the Bryan vote in 1896. Again there was little correlation $(+.13)$ between the change in the Democratic percentage from 1892 to 1896 with the Norwegian Lutheran vote in these ninety-four townships.

Generally, Norwegians lived in heavily Republican counties; consequently, their Republican politics was reinforced by their neighbors. The Republican politics of Norwegian Lutherans in two widely separated Monona County townships, however, is remarkable. Fairview and Willow townships each had Norwegian Lutheran voting concentrations of over forty per cent. Each township also returned a McKinley majority in 1896, while the rest of Monona County voted heavily for Bryan (sixty-three per cent). Apparently the effect of Populism and Bryan on these Norwegian Monona townships was slight. Norwegians, however, were not monolithically Republican. Norwegian Lutheran Democrats were in evidence during the nineties. Jensen believes a considerable number of Norsemen "endorsed free silver." 27 Jensen's assertion is confirmed when a closer look is taken at the Democratic voting of some Norwegian Lutherans in Monona County. Jordan Township, an area of approximately thirty per cent Norwegian Lutheran voters, gave eighty-two per cent of its 1896 ballots to Bryan. Because the number of Jordan voters in 1896 equalled the number of eligible voters according to the 1895 census, close to one-third of Jordan's Norwegian voters must have voted for Bryan. The same situation to a lesser degree was true in neighboring Soldier Township. These deviant Norwegian Lutherans may have been influenced by Populist attitudes in their townships, or saw Bryan as the dry candidate.

Although there were a few Democratic Norwegian Lutherans in rural Iowa, the vast majority were, as the model would predict, Republicans. As is the case for Germans, the model explains the voting of Iowa's Norwegian Lutherans.

\section{Swedish Protestants}

Kleppner estimated that Swedes gave ninety per cent of their

27 Jensen, Winning of the Midwest, 295. 
pre-1896 vote to the Republican party. ${ }^{28}$ According to Jensen, Swedes were "staunch Republican and radical dry" throughout the 1890 s. ${ }^{29}$ The Swedes were so dry that in 1892 a few voters in Freemont Township of Page County (eighty-nine per cent Swedish) actually supported John Bidwell, the tiny Prohibition party's presidential candidate.

During the nineties the Republican percentage of the vote in eight Swedish townships, ${ }^{30}$ as Table III shows, did not change much. Voter turnout, however, increased in 1896. Because this increased turnout did not alter the high Republican percentage, Bryan's candidacy apparently increased voter turnout in Swedish areas among both Republicans and Democrats, Swedes and non-Swedes.

TABLE III

\begin{tabular}{|l|c|c|c|c|c|}
\hline \multicolumn{7}{|l|}{ Vote In Eight SWEDish Townships: $1890-1898$} \\
\hline Election & $\mathbf{1 8 9 0}$ & $\mathbf{1 8 9 2}$ & $\mathbf{1 8 9 4}$ & $\mathbf{1 8 9 6}$ & $\mathbf{1 8 9 8}$ \\
\hline $\begin{array}{l}\text { Republican } \\
\text { Percentage }\end{array}$ & $76.4 \%$ & $75.0 \%$ & $79.6 \%$ & $81.7 \%$ & $81.5 \%$ \\
\hline Turnout & 1287 & 1446 & 1396 & 1804 & 1433 \\
\hline
\end{tabular}

Kleppner found that Swedish Lutherans in the eastern Midwest "tended to give higher levels of support to Bryan than any candidate since the 1850s." He believes the Swedes were alienated from McKinley because of Republican willingness to accommodate groups such as German Lutherans by de-emphasizing prohibition. ${ }^{31}$ Kleppner's analysis, however, does not apply to the Swedes of Iowa. During the nineties Iowa Swedes remained with the Republican party at high levels, unaffected by the candidacy of Bryan.

The model would predict a high level of Republican voting by Swedish Protestants. This phenomenon was found to be true, and supports the model's explanation for the behavior of Iowa's Swedish.

\footnotetext{
${ }^{28}$ See Kleppner, Cross of Culture, 374 for a discussion of the political behavior of Swedish pietists in the eastern Midwest.

${ }^{29}$ Jensen, Winning of the Midwest, 80.

${ }^{30}$ Table III is based on the following eight Swedish townships: Scott $(78.7 \%)$ and Grant $(35.4 \%)$ townships Montgomery County, Lost Grove $(87.8 \%)$ and Dayton $(56.1 \%)$ Webster County, Swea Township (54.3\%) Kossuth County, Wheeler Township $(55.1 \%)$ Sac County, Fairfield Township $(75.9 \%)$ Buena Vista County, and Fremont Township $(89 \%)$ Page County.

${ }^{31}$ Kleppner, Cross of Culture, 375.
} 


\section{Dutch Reformed}

The ethnocultural model would predict a Republican vote by Dutch Reformed. As Map I shows, there were two significant Dutch Reformed settlements. One was in Marion County southeast of Des Moines, and another was in Sioux County near Iowa's northwest corner. Each settlement, strangely enough, had a different voting pattern. As Table IV shows, the model explains the Republican voting of the Sioux Dutch, while the Democratic politics of the Marion Dutch cannot be explained by the model. This difference in voting is remarkable because in the 1870s large numbers of Marion Dutch moved to Sioux County $^{32}$ and apparently changed voting habits.

\section{TABLE IV}

\begin{tabular}{|c|c|c|c|c|c|}
\hline \multicolumn{6}{|c|}{$\begin{array}{l}\text { The Democratic Vote in Two Dutch Reformed Townships: } 1890 \text { - } \\
1898\end{array}$} \\
\hline Year & \multicolumn{2}{|c|}{ Sioux Co., Capel } & \multicolumn{3}{|c|}{$\begin{array}{l}\text { Marion Co., Lake Prairie } \\
\text { Township (Turnout) }\end{array}$} \\
\hline 1890 & SS $44.4 \%$ & ( 72$)$ & & S $81.2 \%$ & (363) \\
\hline 1891 & G $36.9 \%$ & $(84)$ & & $82.2 \%$ & (370) \\
\hline 1892 & P $29.6 \%$ & ( 91$)$ & & $77.2 \%$ & $(400)$ \\
\hline 1893 & G $25.0 \%$ & ( 92$)$ & & $77.8 \%$ & $(365)$ \\
\hline 1894 & SS $25.9 \%$ & (108) & & S $76.2 \%$ & (336) \\
\hline 1895 & G $24.5 \%$ & (102) & & $71.2 \%$ & (348) \\
\hline 1896 & P $\quad 22.0 \%$ & (145) & & $71.4 \%$ & $(384)$ \\
\hline 1897 & G $20.1 \%$ & (134) & & $69.1 \%$ & (314) \\
\hline 1898 & \multicolumn{2}{|c|}{ Unknown } & \multicolumn{2}{|c|}{ SS $67.2 \%$} & (339) \\
\hline \multicolumn{2}{|c|}{$P=$ Presidential Vote } & Gubernato & & $S S=S e c$ & State Vote \\
\hline
\end{tabular}

The unusual voting habits of the Marion Dutch are understandable considering their history. ${ }^{33}$ When the Dutch settled Marion County in the 1850 s they were confronted by xenophobic native American white, Anglo-Saxon Protestants who disliked the presence of Dutch or any foreign group in "their" country.

${ }^{32} \mathrm{Jacob}$ Van der Zee, The Hollanders of Iowa (Iowa City, 1912), 235-37.

${ }^{33}$ See Robert P. Swierenga, "The Ethnic Voter and the First Lincoln Election," Civil War History, XI, 1 (1965), 27-43 for a treatment of the early history of Marion County Dutch. 
Many of these natives supported the Know-Nothing party in the early 1850 s and switched to the Republican party when it formed in the middle 1850s. The Marion Dutch, consequently, reacted against the situation by becoming strong conservative Democrats. This conservatism helps explain the drop between 1892 and 1896 in the Democratic vote in Marion County. ${ }^{34}$ Bryan's talk of easy money may have frightened these conservative Dutchmen.

Sioux Dutch, however, supported Republican candidates, especially in Capel Township, their Sioux County stronghold. The increased Republican percentage in Capel probably reflects the increasing number of Dutch who became eligible to vote in the 1890 s.

The state of Michigan also had large settlements of ardent Republican Dutch; their politics is explained by the ethnocultural model..$^{35}$ That these Michigan Dutch voted Republican, like the Sioux Dutch, underscores the deviant voting pattern of the Marion Dutch, not explained by the model.

\section{Irish Catholics}

During the nineties Iowa's Irish Catholics, as the model would predict, gave high levels of support to Democrats. Some townships actually returned greater Democratic majorities in 1896 than in $1892 .{ }^{36}$ Table V contains seven Irish Catholic townships ${ }^{37}$ and their combined Democratic percentage for the nineties. All seven townships had voting populations at least fifty-five per cent Irish Catholic. As Table V shows, there was a slight overall decrease in the Democratic percentage of the vote. Since third-party movements were not strong in these Irish Catholic areas, this decrease in Democratic percentage benefitted Republicans.

\footnotetext{
${ }^{34}$ Third parties had no measurable support in Dutch areas of Marion County during the nineties.

${ }^{35}$ Kleppner, Cross of Culture, 60.

${ }^{36}$ Jackson Township $(+6.9 \%)$ Webster County, Adams Township $(+6.4 \%)$ Delaware County, Emmetsburg Fourth Ward $(+4.5 \%)$ Palo Alto County, and Hanover Township $(+2.8 \%)$ Allamakee County.

${ }^{37}$ Washington Township $(84.4 \%)$ Jones County, Jackson Township $(68.4 \%)$ Webster County, Great Oak Township (66.9\%) Palo Alto County, Otter Creek $(66.6 \%)$ Jackson County, Taylor Township (67.2\%) Allamakee County, Vernon Township (55.8\%) Dubuque County, and York Township $(55.6 \%)$ Iowa County.
} 
Table V suggests two noteworthy conclusions. First, there was a sharp increase in voter turnout for the 1896 election. Many normally non-voting Irish Catholics were stirred enough by the 1896 election to cast ballots. Second, there was only a temporary gain in Democratic percentage between the 1894 and 1896 elections (the 1898 percentage level declined to the 1894 level), indicating the deviant nature of the Irish Catholic support of Bryan in 1896.

TABLE V

\begin{tabular}{|l|c|c|c|c|c|}
\hline \multicolumn{7}{|c|}{ The Vote in SEVEn Irish CATHolic TownShips: $1890-1898$} \\
\hline Election & $\mathbf{1 8 9 0}$ & $\mathbf{1 8 9 2}$ & $\mathbf{1 8 9 4}$ & $\mathbf{1 8 9 6}$ & $\mathbf{1 8 9 8}$ \\
\hline $\begin{array}{l}\text { Democratic } \\
\text { Percentage }\end{array}$ & $84.3 \%$ & $79.8 \%$ & $74.4 \%$ & $78.7 \%$ & $75.7 \%$ \\
\hline Turnout & 1020 & 1171 & 1068 & 1340 & 1079 \\
\hline
\end{tabular}

Surprisingly, during the nineties Irish Catholic voters in ninety-four townships across Iowa correlated weakly with the Democratic presidential vote. In 1892 the Irish correlated at +.20 and in 1896 their coefficient rose to +.39 . Overall, Irish correlated with the change in Democratic percentage between 1892 and 1896 at +.35 . The fifteen townships ${ }^{38}$ with the highest percentage of Irish correlated slightly more with the Democratic percentage change from 1892 to 1896 with a correlation of +.40 .

These slight changes in Irish Catholic voting during the 1890s are beside the point, which is: Iowa Irish Catholics, despite Bryan's candidacy, turned out in large numbers and supported Democrats-behavior the model explains.

\section{Bohemians}

Iowa Bohemians historically have not been strong supporters of the Republican party. ${ }^{39}$ This was no less true in the nineties when four heavily Bohemian townships ${ }^{40}$ in eastern Iowa dis-

\footnotetext{
${ }^{38}$ In addition to those listed in note 37: Emmetsburg City Third $(58.8 \%)$ and Fourth $(55.8 \%)$ Wards Palo Alto County, French Creek $(53.9 \%)$ and Hanover $(52 \%)$ townships Allamakee County, Emmetsburg Township $(49.1 \%)$ Palo Alto County, Dover Township (48\%) Pocahontas County, Cedar Township $(46.8 \%)$ Greene County, and Adams Township $(39 \%)$ Delaware County.

${ }^{39}$ Jensen, Winning of the Midwest, 112.

${ }^{40}$ Monroe Township $(86 \%)$ Johnson County, New Oregon Township $\mathbf{( 4 2 . 6 \% )}$ Howard Township, Otter Creek Township $(55.6 \%)$ Tama County, and Center Township $(26.5 \%)$ Pocahontas County. 
played remarkable constancy with the Democratic party. For example, Monroe Township in Johnson County, eighty-six per cent Bohemian with a large minority of German Catholics, gave over ninety per cent of its vote to the Democrats in both 1892 and 1896. Bohemians in homogeneous rural areas clearly voted Democratic throughout the critical realigning period of the nineties despite Bryan's candidacy. The model would forecast Democratic Bohemian voting; thus the model's prediction for Bohemians' voting behavior generally holds true in Iowa.

\section{Luxemburg Catholics}

Late in the nineteenth century many Luxemburgers settled Iowa. By 1885 there were 285 families in Jackson County and more than 450 families in Dubuque County to the north. Most of the Luxemburgers were Catholics; some, however, were Lutherans..$^{41}$ The 1895 census shows two townships with heavy concentrations of Luxemburg Catholics: Prairie Springs Township in Jackson County with a voting population 55.5 per cent Luxemburg Catholic and Mosalem Township in Dubuque County with a voting population 43.5 per cent Luxemburg Catholic.

During the nineties these two communities mirrored the German Catholics in their voting, giving the Democratic party preponderant support. Accordingly, the model's explanation for German Catholic voting holds true for Iowa's Luxemburg Catholics. Each township experienced a slight decline in Democratic percentage between the election of 1892 and 1896 . The Democratic percentage in Prairie Springs Township fell from 86.6 per cent to 72.0 per cent and Mosalem from 80.3 per cent to 72.0 per cent. But this decline conforms to the voting behavior of the German Catholics.

\section{Danish Lutherans}

Two townships had large concentrations of Danish Lutherans: Denmark Township in the northern Iowa county of Emmet and Jackson Township in the western Iowa county of Shelby had voting populations of 65.5 and 51 per cent Danish Lutheran respectively. As Table VI shows, these townships voted differ-

\footnotetext{
${ }^{41}$ Hubert Moeller, "They Settled Here: E. Iowa Hospitable to Luxembourgers," Des Moines Sunday Register, November 23, 1975, 2c.
} 
voted differently during the nineties, a split consistent with the model.

Denmark Township generally voted Republican; and a high voter turnout corresponded to a high Republican vote while a low turnout corresponded to a low Republican vote, as indicated by Table VI. The turnout in Denmark Township was very low in non-presidential elections. Apparently some voters within Denmark Township stayed home in non-presidential years. Whether Danish Lutheran voters abstained is uncertain. The Danes of Denmark Township clearly did not record a consistent vote for one or another party throughout the decade as did the Norwegian Lutherans, Irish Catholics and Bohemians.

TABLE VI

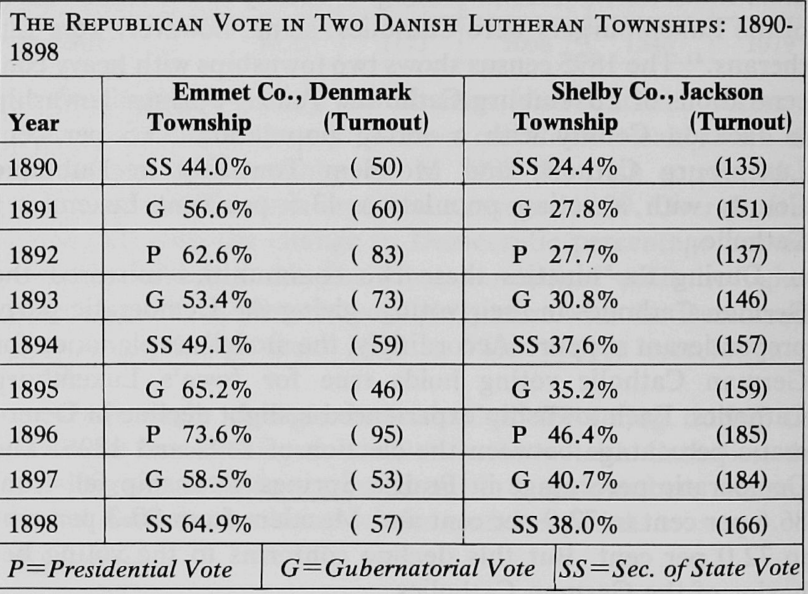

A Democratic trend in the voting returns of Jackson Township is support for Jensen's idea that some Danish Americans favored free silver and voted for Bryan. ${ }^{42}$ But Jackson Township went heavily Democratic in 1890, 1891 and 1892 when free silver could not have been a strong motive for Democratic voting. Further, the comparatively high Republican percentage in 1896 tends to contradict the thesis that free silver was completely re-

${ }^{42}$ Jensen, Winning of the Midwest, 295. 
sponsible for drawing the Danes to the Democratic standard.

This split between Iowa's two heaviest concentrations of Danish Lutherans is explained by the model, entirely predictable from Kleppner's estimates in Table I. Midwestern Danes, the model holds, were divided in their loyalties; their voting was not based on ethnic factors. The evidence shows that Iowa Danes were no exception.

ThE ETHNOCULTURAL MODEL of midwestern voting, developed by historians such as Kleppner and Jensen, generally is precise in explaining the realignment of rural Iowa ethnics in the nineties. The pietistic Swedish and Norwegian Lutherans maintained their Republican voting throughout the nineties. Traditionally Democratic liturgicals-Bohemians and Irish Catholics -voted slightly more Republican. Both German Lutherans and German Catholics shifted toward the Republican party. German Lutherans, however, shifted toward Republicans in larger numbers than German Catholics, a behavior found in other states. The 1890 s voting of Dutch and Danish Pietists, however, is not explained by their ethnocultural backgrounds. Iowa settlements of these two groups exhibited separate political behavior. Each Danish or Dutch township, however, did show a Republican trend throughout the decade, just what the model would predict. During the nineties rural Iowa ethnics, with few exceptions, became more Republican. 
Copyright of Annals of Iowa is the property of State of Iowa, by \& through the State Historical Society of Iowa and its content may not be copied or emailed to multiple sites or posted to a listserv without the copyright holder's express written permission. However, users may print, download, or email articles for individual use. 